\title{
The Relative Influence of Consumer Innovativeness, Brand Loyalty, and Deal Proneness on New Product Adoption: A Direct Product Experience Study
}

\author{
Olimpia C. Racela \\ Mahasarakham University, Mahasarakham, Thailand
}

Correspondence should be addressed to: Olimpia C. Racela; olimpia.r@acc.msu.ac.th

Received date: 29 August 2014; Accepted date: 10 December 2014; Published date: 15 December 2015

Academic Editor: Nasreen khan

Copyright @ 2015 . Olimpia C. Racela . Distributed under Creative Commons CC-BY 4.0

\begin{abstract}
When consumers are introduced to new products, they often undergo a complex decision making process. Adopting an approach-avoidance conflict framework, this study examines the influence of three consumer dispositions, specifically consumer innovativeness, brand loyalty, and deal proneness on the adoption of an innovative premium consumer product being marketed under a new brand name. A panel of 132 households comprising a total of 493 consumers participated in a one-week trial of the new product/brand during which both pre- and post- test data were collected. Hypotheses were tested using structural equation modeling and multiple-group analyses to assess the moderating effects of demographic characteristics. The pooled results reveal that deal proneness (an avoidance mechanism) has the strongest influence on new product adoption, which contradicted the initial hypothesis of a negative relationship. The next strongest influence on new product adoption is consumer innovativeness (an approach mechanism), in the hypothesized positive direction. Brand loyalty (an avoidance mechanism) has a moderate negative influence as hypothesized. These influences are consistent between older and younger, as well as male and female consumer groups. These findings offer important implications to marketers of new products and provide directions for future research.
\end{abstract}

Keywords: consumer innovativeness, brand loyalty, deal proneness, new product adoption

\section{Introduction}

Interest in new product adoption among academics and managers has increased in importance as a result of the rapid influx of new product launches and the high failure rate of 95 percent (Nobel, 2011). A new product that is equipped with superior features over existing products gives some reason for adoption, but a consumer's loyalty to an existing brand and the perceived financial and social risks of adoption may inhibit trial and purchase. These consumer dispositions of innovativeness, brand loyalty and deal proneness are among the most highly discussed in the consumer behavior 
and in the market segmentation literature, yet they have never been empirically examined simultaneously in a single study. This is surprising given that marketing scholars offer diverse views of the interplay between these dispositions, with some claiming that consumer innovators are deal prone and less brand loyal (e.g. Schiffman and Wisenblit, 2014; Tyagi and Kumar, 2004) and some claiming otherwise (e.g. Yoon and Tran, 2001).

The purpose of this study is to examine the relative influence of consumer innovativeness, brand loyalty to an existing brand, and deal proneness on the adoption of a highly innovative premium priced product marketed under a new brand name. In doing so, this paper contributes to the extant research on new product adoption (NPA) in three ways. First, it expands the nomological network of NPA by empirically examining consumer dispositions that have not yet been examined simultaneously. Second, within our avoidance-approach conflict framework, we integrate a contingency perspective to compare hypothesized relationships between gender and age groups. This is important to marketers, who tend to apply both behavioral and demographic characteristics for segmentation purposes. Third, our study involves a panel of consumers undertaking a one-week product trial, giving our participants direct product experience, which enabled us to obtain more accurate purchase intention responses
(Mason et al., 2001; Wood and Moreau, 2006). Moreover, because many prior NPA studies have relied on experimental stimuli or simulated new products (e.g. Timmor and Katz-Navon, 2008) or on a retrospective approach (e.g. Im et al., 2003), direct product experience approaches are more appropriate means to obtain greater practical significance (Payne and Wansink, 2011).

\section{Theoretical Foundations and Hypotheses Development}

A consumer's choice process often presents an approach-avoidance conflict, where NPA poses both positive and negative consequences that make the new product both appealing and unappealing simultaneously (Miller, 1959). When the consequences of positive effects outweigh those from negative ones, NPA is likely to occur. We adopt this perspective to develop a conceptual model linking NPA with consumer innovativeness as an approach mechanism and brand loyalty and deal proneness as avoidance mechanisms. Our research context involves a highly innovative product/brand positioned at a premium price level. Thus, our basic premise is that NPA is more likely to be adopted by highly innovative consumers who are less brand loyal and less deal prone. We also integrate a contingency approach to posit the moderating effects of gender and age on the influence of consumer dispositions on NPA. Our conceptual model is depicted in Figure 1.

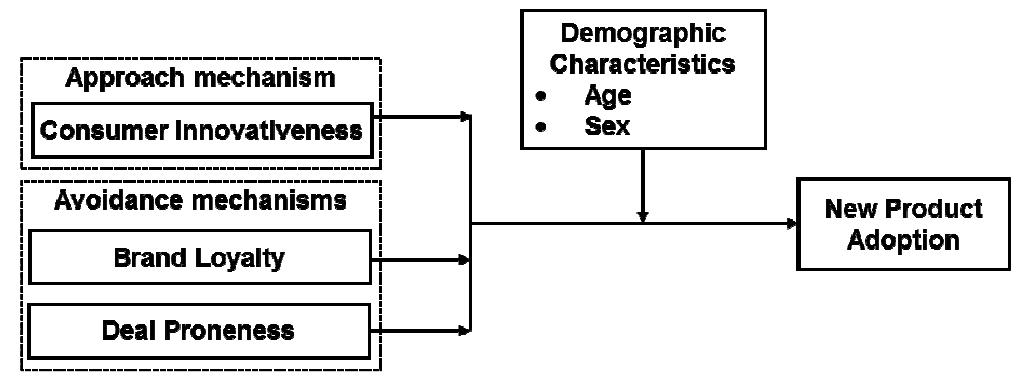

Figure 1: Conceptual Model

\section{Consumer Innovativeness and New Product/Brand Adoption}

Consumer innovators are critical to new product success because their early adoption builds legitimacy and fosters further diffusion of the product. Broadly stated, consumer innovativeness is an inherent psychological trait describing one's tendency to adopt new products ahead and independent of others (Tellis et al., 2009). A review of the studies on consumer 
innovativeness and NPA reveals that the relationship is not so straightforward (e.g. Hirunyawipada and Paswan, 2006) and varies between cultures (e.g. Lim and Park, 2013). As such, the relationship between consumer innovativeness and NPA is context-specific.

At a fundamental level, individual needs of arousal and novelty-seeking are underlying reasons for consumer innovativeness (Chau and Hui, 1998; Hirschman, 1980). Motives for NPA have also been explained by meansend chain (MEC) theory (Gutman, 1982). In an NPA situation, when consumer innovators associate the new product with positive emotions, the new product (i.e. means) achieves the consumer's desired state (i.e. end). This is particularly true when the new product offers relative advantages over the existing products. Thus, within an approachavoidance conflict framework, consumer innovativeness is an approach mechanism. A means-end view implies that the consumption of new products may be driven by the need to maintain or advance into a higher status in society (Wang et al., 2005). Based on theory and prior research, we expect consumers with a high degree of innovativeness to be more likely to adopt a new product/brand than those who are less innovative. Therefore, it is proposed that:

H1: Consumer innovativeness has a positive influence on the consumer's adoption of the new product.

\section{Brand Loyalty and New Product/Brand Adoption}

Creating brand loyalty is one of the primary objectives of packaged goods brand promotions because of the widely recognized benefits gained from brand loyal customers. In this paper, brand loyalty is broadly defined as a consumer's tendency to purchase the same brand, rather than other brands, in a particular product category over time (Tam et al., 2009). Brand loyalty is a learned behavior derived from a consumer's accumulated knowledge and experience from the product usage of one or several brands in a product category (Moreau et al., 2001). Firms with brand loyal customers may benefit in a number of ways, such as in lower costs for promotions and customer maintenance programs. Brand loyalty discourages brand switching and as a behavioral characteristic, brand loyalty has been widely advocated as a segmentation variable because brand loyal customers are a deterrent for new brand entrants (Kotler and Keller, 2010). Brand loyal customers who are satisfied with and committed to a brand they currently use, are less likely to switch to a new brand, respond less to deals offered by competitors of their 'favorite' brand, and are more likely to adopt only innovations associated with their 'favorite' brands (i.e. brand extensions). For these reasons, consumers who are loyal to an existing brand present little opportunity to firms that are launching a new product and brand.

Brand loyalty behaviors can be explained by economic utility theory, which states that consumers will purchase products that increase their personal satisfaction. Marketers launching a completely new brand are more interested in consumers in the market who show low or no brand loyalty. Such loyalty-lacking consumers are more receptive to substitute products and brands. Alternatively, consumers loyal to an existing brand may be inclined to compare a new brand's features with those of their favored brand; however, high switching costs that may have accumulated over time from the usage of a brand may act as an avoidance mechanism. Such inherent costs ultimately deter brand loyal consumers from adopting new products and brands. Therefore, for our study, it is proposed that:

H2: Brand loyalty to a current product/brand has a negative influence on new product/brand adoption.

\section{Deal Proneness and New Product/Brand Adoption}

For the launch of new products, deals are offered in order to make it more appealing and to reduce consumers' perceived risks of adoption. Such deal incentives include coupons, introductory discounts, premiums, rebates, etc. which positively affect purchase evaluations (Lichtenstein et al., 1990). Consumers who are deal prone have the propensity to purchase products when an 
additional temporary 'incentive' augments the market offer (Hackleman and Duker, 1980). Deal prone consumers are often described as heavy users, lower income earners, price-sensitive, and non-loyal to brands. Some research findings support these notions. For instance, Hackleman and Duker (1980) find that deal prone consumers tend to be more price sensitive while Lynn (2011) finds they are heavy users who like to try new brands. For these reasons, deal proneness has been described as a practical and meaningful segmentation bases.

When considering the adoption of a new product, a consumer may compare the new product's features and performance with those of the existing products. The comparison may also include an valuation of the new product by comparing its selling price to those of the current products and brands. The theory of reference-price perceptions helps to explain the role of deals in NPA (Lowe and Barnes, 2012). Reference prices are standards by which a consumer compares the price of one product to a known price level, which could be based on an average of prices of different brands or on a customary price charged in a product category. In a situation where a highly innovative but substantially higher priced new product is launched in a seemingly commoditized product category, deal prone consumers would likely be less interested in the 'expensive' new product. Thus, deal proneness acts as an avoidance mechanism for NPA. In our context, with the new product positioned at a substantially higher premium price level, consumers may perceive greater financial risk, which would inhibit its adoption. Therefore, the following is hypothesized:

H3: Deal proneness has a negative influence on the adoption of a new product/brand.

\section{The Contingent Role of Demographic Characteristics}

There is a general consensus that new products are adopted early by consumers who have higher levels of income, have higher education and are younger in age (e.g. Gatignon and Robertson, 1985; Wang et al., 2008). Our interest lies in the moderating effects of gender and age on the relationship between consumer disposition and NPA because these two characteristics are widely used for market segmentation purposes. We adopt a contingency perspective and argue that the influence of consumer dispositions on NPA depend upon the consumer's age and gender. Thus, we hypothesize:

H4: The relationship between consumer dispositions and NPA varies between consumer (a) gender and (b) age groups.

\section{Research Methodology}

This study was designed as a pretest-posttest one-week product trial implemented in Bangkok, Thailand. The new product was a liquid form of toothpaste marketed under the brand, Hapica. A 600 milligram bottle was sold at retail between 360 to 420 baht (US $\$ 11.75$ to US $\$ 13.70$ ), nearly five times higher than the average price of the standard tube size (i.e. 220 milligram). This product was virtually unknown in Thailand at the time of the study.

\section{Participants}

The target population of the study was affluent consumers in Bangkok. Purposive sampling was employed to control for purchasing power. Therefore, participating households had to have a minimum gross monthly income of Bht150,000 (US\$4,890). Additionally, we sought household sizes of four that included parents and children 15 years of age or older. This household composition was necessary to ensure that a wide range of consumer ages could be included in the study.

\section{Data Collection}

Eligible participants were instructed of the research design and were asked to sign a consent form agreeing to comply with research procedures. Then, participants completed the pre-test questionnaire, which comprised questions about consumer dispositions. Then, the head of the household was given a $600 \mathrm{ml}$. bottle of Hapica and all participants were instructed to brush their teeth for one week using the Hapica product exclusively. After the trial, participants were 
revisited, asked to complete a postquestionnaire with questions about new product purchase intention, then were debriefed of the study.

\section{Survey Instrument Development}

Existing multi-item measures were adopted and adapted for our context. The original English scales were translated to Thai by two independent bilinguals. The instrument was pre-tested by 30 consumers. All multi-item scales were measured on four-point Likert scales. Consumer innovativeness (CINNOV) was measured using scale developed by Goldsmith and Hofacker (1991). Item five of the original scale, "I will buy a new product, even if I haven't heard it yet," was omitted due to pretest respondents' difficulty understanding the translation. Brand loyalty (BLOYAL) was measured by the scales of Putrevu and Lord (1994) and of Mittal (1994). Deal proneness (DEALPR) was measured by the scale of Putrevu and Ratchford (1997). New product adoption (NPADOPT) was measured by the purchase intention scale developed by Putrevu and Lord (1994). The participant gender was recorded as a dummy variable while age was measured in years.

\section{Analysis and Results}

\section{Sample Characteristics}

Data were collected from an initial panel of 532 participants from 132 households. However, 35 pretest-posttest sets were eliminated due to incompleteness or participant mortality. The final number of cases analyzed was 497. The sample characteristics are reported in Table 1 . The socio-economic status of the sample is higher than that of the general Thai population.

\section{Data Analyses}

Responses were input to SPSS v.20. The data did not violate assumptions of linearity nor of normality. A Harman's single-factor test (Podsakoff et al., 2003) of all the items from the four constructs indicated common method bias was not present. The scales were assessed with reliability analysis. Items with item-to-total correlations below 0.40 (i.e. one from the CINNOV scale and one from the BLOYAL scale) were excluded from further analyses. The research model was tested using AMOS v.17. The first-order structural equation model including CINNOV, BLOYAL, and DEALPR as endogenous latent constructs, and NPADOPT as the exogenous latent construct was analyzed.

Table 1: Sample Characteristics

\begin{tabular}{|c|c|c|c|}
\hline Characteristic & Proportion (count) & Age Range & Mean Age \\
\hline $\begin{array}{c}\text { Gender } \\
\text { Female } \\
\text { Male }\end{array}$ & $\begin{array}{ll}56.1 \% & (279) \\
43.9 \% & (218)\end{array}$ & $\begin{array}{l}15-82 \\
15-71\end{array}$ & $\begin{array}{l}35 \text { years } \\
38 \text { years }\end{array}$ \\
\hline $\begin{array}{l}\text { Education completed } \\
\text { High school/college student } \\
\text { Bachelor's degree } \\
\text { Master's degree and higher }\end{array}$ & $\begin{array}{ll}29.5 \% & (147) \\
60.0 \% & (298) \\
10.5 \% & (52) \\
\end{array}$ & & \\
\hline $\begin{array}{l}\text { Occupation } \\
\text { Student (high school, undergraduate, } \\
\text { graduate) } \\
\text { Business owner } \\
\text { Top executive } \\
\text { Company employee } \\
\text { Housewives } \\
\text { Retiree } \\
\end{array}$ & $\begin{aligned} 36.0 \% & (147) \\
30.0 \% & (298) \\
4.4 \% & (52) \\
17.0 \% & (147) \\
11.0 \% & (298) \\
1.6 \% & (52)\end{aligned}$ & & \\
\hline
\end{tabular}




\section{Measurement Model Validation}

From the measurement model, the standardized factor loadings and their corresponding $t$-values are significant, indicating convergent validity, as reported in Table 2. Additionally, the square root of the average variance extracted (AVE) in the diagonal elements is greater than the offdiagonal elements, which meets the criterion of the discriminant validity (Fornell and Larcker, 1981). Consequently, the psychometric properties of the four multiitem constructs are acceptable for internal reliability (i.e. Cronbach's alpha, $\alpha$ ), composite reliability $\left(\rho_{c}\right)$, and $\operatorname{AVE}\left(\rho_{\mathrm{v}}\right)$, as CINNOV $\left(\alpha=0.773, \rho_{c}=0.876\right.$, and $\rho_{\mathrm{v}}=$ $0.641)$, BLOYAL $\left(\alpha=0.801, \rho_{\mathrm{c}}=0.891\right.$, and $\rho_{\mathrm{v}}$ $=0.624)$, DEALPR $\left(\alpha=0.857, \rho_{c}=0.921\right.$, and $\left.\rho_{\mathrm{v}}=0.701\right)$, and NPADOPT $\left(\alpha=0.886, \rho_{\mathrm{c}}=\right.$ 0.902 , and $\rho_{v}=0.756$ ) are within the recommended thresholds (Fornell and Larcker, 1981).

Table 2: Construct Descriptive Statistics

\begin{tabular}{|l|c|c|c|c|c|c|c|c|}
\hline Construct & $\begin{array}{c}\text { No. of } \\
\text { Items }\end{array}$ & $\begin{array}{c}\text { Range of Factor } \\
\text { Loadings }\end{array}$ & Mean & Std. Dev. & $\mathbf{1}$ & $\mathbf{2}$ & $\mathbf{3}$ & $\mathbf{4}$ \\
\hline 1. CINNOV & 4 & $0.567-0.735$ & 2.61 & 0.541 & $\mathbf{. 8 0 0}$ & & & \\
\hline 2. BLOYAL & 5 & $0.560-0.756$ & 2.77 & 0.524 & $-.188^{* * *}$ & $\mathbf{. 8 9 5}$ & & \\
\hline 3. DEALPR & 5 & $0.610-0.806$ & 2.31 & 0.576 & $-.109^{* * *}$ & .075 & .926 & \\
\hline 4. NPADOPT & 3 & $0.768-0.961$ & 3.18 & 0.844 & $.116^{* * *}$ & $-.093^{* * *}$ & $.172^{* * *}$ & $\mathbf{. 9 4 1}$ \\
\hline
\end{tabular}

Square root of the AVE of the construct lies along the diagonal.

$* * * \mathrm{p}<0.01 ; * * \mathrm{p}<0.05 ; * \mathrm{p}<0.10$.

\section{Structural Model Estimation}

The structural model was then analyzed to test hypotheses 1 to 3 (Byrne, 2010). Path coefficients were estimated using maximum likelihood (Bollen, 1989). The goodness-of-fit measures indicate an acceptable model fit, with $\chi^{2}{ }_{(116)}=240.543, \mathrm{GFI}=.945, \mathrm{IFI}=.962$, $\mathrm{TLI}=.955, \mathrm{CFI}=.962, \mathrm{RMSEA}=.047$ against the cutoff criteria of Browne and Cudeck (1993).
The structural path estimates are reported in table 3. Consistent with our expectation, the estimation results show that CINNOV influences NPADOPT significantly and positively at the .05 level $(\gamma=.167, \mathrm{p}=.031)$. Thus, $\mathrm{H} 1$ is supported. The results also show that BLOYAL significantly discourages NPA $(\gamma=-.148, \mathrm{p}=.067)$ at the .10 level, providing support of H2. In contrast to our prediction, the path from DEALPR to NPADOPT is positive and significant $(\gamma=.293, \mathrm{p}=.000)$ at the .01 level. Thus, $\mathrm{H} 3$ is not supported.

Table 3: Summary of Results for Hypotheses Tests of H1-H3

\begin{tabular}{|l|c|c|c|c|}
\hline \multicolumn{1}{|c|}{ Hypothesis } & $\begin{array}{c}\text { Expect } \\
\text { ed Sign }\end{array}$ & $\begin{array}{c}\text { Standardized } \\
\text { Regression } \\
\text { Estimate }\end{array}$ & t-value & Results \\
\hline H1: CINNOV -> NPADOPT & + & $0.111^{* *}$ & 2.161 & Supported \\
\hline H2: BLOYAL -> NPADOPT & - & $-0.092^{*}$ & -1.829 & Supported \\
\hline H3: DEALPR -> NPADOPT & - & $0.222^{* * *}$ & 4.454 & Not supported \\
\hline
\end{tabular}

\section{Multiple Group Analyses}

Hypothesis $4 \mathrm{a}$ and $4 \mathrm{~b}$ stated that the relationship between consumer innovativeness, brand loyalty, and deal proneness and NPA would vary between different gender and age groups. We assessed measurement invariance by setting equal factor loadings of the demographic subgroups. We did not find a decrease in model fit for neither gender $\left(\chi^{2}\right.$ diff $=12.951$, $\Delta$ d.f. $=13, \mathrm{p}=.452)$ nor for age $\left(\chi^{2}\right.$ diff $=$ 11.243, $\Delta$ d.f. $=13, p=.590$ ), thus indicating measurement equivalence. 
Subsequently, we added constraints to the structural weights to be equal between demographic groups and re-estimated the empirical models. The results show that there are no significant structural differences between females and males $\left(\chi^{2}\right.$ diff $=13.284$, $\Delta$ d.f. $=16, \mathrm{p}=.652$ ), as shown in Table 4 . Thus, hypothesis $\mathrm{H} 4 \mathrm{a}$ is not supported, as gender does not moderate the relationships between our three consumer dispositions and NPADOPT. The results also show that there are no significant differences in the structural parameters between younger and older consumers $\left(\chi^{2}\right.$ diff $=14.831, \Delta$ d.f. $=16, p$ $=.537)$. Therefore, no support is found for $\mathrm{H} 4 \mathrm{~b}$.

Table 4: Multiple Group Analyses Results

\begin{tabular}{|l|l|c|c|c|c|}
\hline & & \multicolumn{2}{|c|}{ Unstandardized regression weights } & \\
\hline Hypothesis & $\begin{array}{l}\text { Moderator } \\
\text { Variable }\end{array}$ & $\begin{array}{c}\text { CINNOV-> } \\
\text { NPADOPT }\end{array}$ & $\begin{array}{c}\text { BLOYAL-> } \\
\text { NPADOPT }\end{array}$ & $\begin{array}{c}\text { DEALPR-> } \\
\text { NPADOPT }\end{array}$ & $\begin{array}{c}\boldsymbol{\chi}^{2} \text { Diff. } \\
\text { (sig.) }\end{array}$ \\
\hline H4a & Sex & & & & \\
& Female & $.176, p=.076$ & $-.102, p=.358$ & $.294, p=.002$ & 13.284 \\
& Male & $.140, p=.242$ & $-.171, p=.136$ & $.224, p=.010$ & $p=.652$ \\
\hline H4b & Age & & & & \\
& Younger & $.147, p=.130$ & $-.014, p=.895$ & $.300, p=.000$ & 14.831 \\
& Older & $.184, p=.122$ & $-.297, p=.016$ & $.254, p=.013$ & $p=.537$ \\
\hline
\end{tabular}

\section{Discussion}

The aim of this study was to get a deeper understanding of the influence of three consumer dispositions on the adoption of a premium innovative product marketed under a new brand name. The findings suggest that the more innovative consumers are, the more likely they are to adopt the new product, which is consistent with the findings of several other previous studies (e.g. Cowart et al., 2008; Im et al., 2003). Additionally, since our focal product is of a premium level, our results reaffirm the results of Goldsmith et al. (2010), who find that consumer innovators are less price sensitive. We sought deeper insights on the highly innovative consumers in our sample and conducted post hoc analyses by using a split mean method to create two consumer innovator groups (i.e. low and high). Then we compared these two groups on other characteristics. We find that consumer innovators are more likely to be female $\left(\chi^{2}=\right.$ 4.242; $p=.041$ ). Our consumer innovators also have a higher propensity to be brand loyal $\left(\chi^{2}=6.379 ; p=.013\right)$, which is consistent with the findings of Aroean (2012) and those of Ramirez and Goldsmith (2009).

Our data also reveal that NPA is lower when the consumer is highly loyal to an existing brand, which is consistent with much of the consumer research on brand extensions (e.g. Kotler and Keller, 2010). However, it is worth noting that brand loyalty has the relatively smallest influence on NPA. According to Klemperer (1995), brand loyalty or switching costs can be altered when uncertainty of the new product can be reduced via actual product usage. Thus, we believe that the slight influence of brand loyalty in our sample may be due to the learning that took place during the product trial, whereby participants used the new product, experienced its benefits, and evaluated its performance reduced any uncertainties of the new toothpaste.

The finding of the relationship between NPA and deal proneness is especially intriguing. Against our expectations, we find that NPA is more likely when the consumer has a strong disposition for deals. In essence, our study reveals that deal prone consumers may be willing to adopt premium priced innovative products. What explains this contrary finding? It is plausible that our measure of deal proneness captures a consumer's valueseeking tendencies (e.g. "I look for unadvertised specials offered by supermarkets," and "I look for special displays in supermarkets.") in addition to the deal and/or price related incentives (e.g. "I wait until there is an advertised sale before 
going to shop at a store."). That is, the highly 'deal prone' consumers in our sample may have be drawn to the premium priced new product because they believe it delivers actual relative advantages over existing products.

Finally, our findings provide insights on the influence of consumer disposition on NPA across sex and age groups. From our sample of affluent consumers, new product adoption is driven by deal proneness, consumer innovativeness, and brand loyalty equivalently across different sex and age groups. This highlights the reputed homogeneity of the Thai consumer market, as noted in much of the extant literature on Thai culture. Additionally, since our sample comprised family members, our findings provide some evidence reaffirming the influence of family members on individual household member innovative behaviors (Cotte and Wood, 2004).

In summary, our study provides empirical support that describes the decision-making complexities that consumers may experience when exposed to innovative products. Our study suggests that the adoption of a new premium product is most influenced by consumers' desire for better deals (i.e. better quality rather than lower prices), followed by their desire for experiencing new things (i.e. consumer innovativeness), then by their loyalty to their current favored brand (i.e. brand loyalty).

\section{Implications for Managers}

There are several major implications for managers of new product launches, particularly launches of premium and higher priced consumer innovations. In terms of segmentation approaches, findings from our study provide evidence that segmenting a market based on the characteristic of consumer innovativeness alone may be insufficient to identify an appropriate segment for new product adoption. Other consumer dispositions, e.g. deal/value proneness as in our study, may be more relevant or influential in determining new product adoption. Additionally, managers are reassured in knowing that the segmentation of markets by consumer psychological traits or consumer dispositions is more meaningful than the segmentation that is focused on demographic bases, i.e. sex and age. All too often marketers rely solely or mainly on the demographic characteristics for segmentation because such characteristics are apparent and can be identified and measured with greater ease. As such, multiple segmentation bases should be applied in order to uncover a more accurate segment to target.

The fact that deal prone consumers are willing to purchase a premium priced new product has important implications for marketers designing promotional programs. The findings suggest that managers should appeal to consumers who are value-seeking rather than those that are merely deal prone. Thus, the market offer of a new premium product might not need to include deal incentives and/or price reductions, which are costly and may also shrink the new product's profit earnings. Instead, marketing budgets can be invested in marketing communications (e.g. advertising) programs to promote the new product's augmented benefits and/or relative advantages. Such communications strategies integrated with new product trials or samples would influence the consumer's assessment of the new product's performance and perceived quality. Keeping in mind that value is a function of both price and perceived quality, marketers who focus on the new product's value creation rather than on reducing consumer's perceived financial risks may be better off in encouraging new product trial and adoption that could eventually lead to continued diffusion in the marketplace.

\section{Limitations and Directions for Future Research}

This study is subject to several limitations. First, our results are limited to our sample of Thais of affluent households, thus the results should not be generalized. Caution was taken during the implementation of the preposttest research design to ensure the internal validity of our study. Replications of this study with other samples of randomly drawn consumers are necessary to determine the external validity of the hypothesized model tested here. Another 
limitation is our one new product/brand context (i.e. premium innovative premium fast-moving consumer good) and therefore, our results may differ in other new product situations, such as a premium durable product (e.g. next generation smartphone), or lower-priced FMCGs (e.g. new energy drink). Future studies employing different new product contexts are needed to assess the consistency of the relationships found in this study. Lastly, our investigation did not include all variables that could potentially influence new product adoption. Knowing this, future research should include other constructs that are likely linked to new product adoption, particularly other approach and avoidance mechanisms such as perceived self-efficacy, materialism, pricesensitivity, frugality and so on.

\section{Acknowledgements}

This research was funded by a grant from Mahasarakham University. The author is grateful to Amonrat Thoumrungroje and Thitiphat Podok for their constructive comments on an earlier version of this paper.

\section{References}

1. Aroean, L. (2012), 'Friend of Foe: In Enjoying Playfulness, Do Innovative Consumers Tend to Switch Brand?' Journal of Consumer Behavior, 11 (1), 67-80.

2. Bollen, K.A. (1989), Structural Equations with Latent Variables, John Wiley \& Sons, New York, New York.

3. Browne, M.W. and Cudeck, R. (1993), 'Alternative Ways of Assessing Model Fit,' in Testing Structural Equation Models, Long, J.S. (ed), Sage, Newbury Park, California.

4. Byrne, B.M. (2010), Structural Equation Modeling with AMOS: Basic Concepts, Applications, and Programming, 2nd Edition, Routledge, New York, New York.

5. Chau, P.Y.K. and Hui, K.L. (1998), 'Identifying Early Adopters of New IT Products: A Case of Windows 95,' Information and Management, 33 (5), 225230.
6. Cohen, A. (1983), 'Comparing Regression Coefficients across Subsamples: A Study of the Statistical Test,' Sociological Methods and Research, 12 (1), 77-94.

7. Cotte, J. and Wood, S.L. (2004), 'Families and Innovative Consumer Behavior: A Triadic Analysis of Sibling and Parental Influence,' Journal of Consumer Research, 31 (1), 78-86.

8. Cowart, K.O., Fox, G.L. and Wilson, A.E. (2008), 'A Structural Look at Consumer Innovativeness and Self-congruence in New Product Purchases,' Psychology \& Marketing, 25 (12), 1111-1130.

9. Fornell, C. and Larcker, D.F. (1981), 'Evaluating Structural Equation Models with Unobservable Variables and Measurement Error,' Journal of Marketing Research, 18 (3), 39-50.

10. Gatignon, H. and Robertson, T.S. (1985), 'A Propositional Inventory for New Diffusion Research,' Journal of Consumer Research, 11 (4), 859-67.

11. Goldsmith, R.E., Flynn, L.R. and Kim, D. (2010), 'Status Consumption and Price Sensitivity,' Journal of Marketing Theory \& Practice, 18 (4), 323-338.

12. Goldsmith, R.E. and Hofacker, C.F. (1991), 'Measuring Consumer Innovativeness,' Journal of the Academy of Marketing Science, 19 (3), 209-221.

13. Gutman, J. (1982), 'A Means-end Chain Model Based on Consumer Categorization Processes,' Journal of Marketing, 46 (2), 6672.

14. Hackleman, E.C. and Duker, J.M. (1980), 'Deal Proneness and Heavy Usage: Merging Two Market Segmentation Criteria,' Journal of the Academy of Marketing Science, 8 (4), 332-344.

15. Hirschman, E.C. (1980), 'Innovativeness, Novelty Seeking, and Consumer Creativity,' Journal of Consumer Research, 7 (4), 283-295.

16. Hirunyawipada, T. and Paswan, A.K. (2006), 'Consumer Innovativeness and 
Perceived Risk: Implications for High Technology Product Adoption,' Journal of Consumer Marketing, 23 (4), 182-198.

17. Im, S., Bayus, B.L. and Mason, C.H. (2003), 'An Empirical Study of Innate Consumer Innovativeness, Personal Characteristics, and New Product Adoption Behavior,' Journal of the Academy of Marketing Science, 31 (1), 61-73.

18. Klemperer, P. (1995), 'Competition when Consumers have Switching Costs: An Overview with Applications to Industrial Organization, Macroeconomics, and International Trade,' Review of Economic Studies, 62 (4), 515-539.

19. Lichtenstein, D.R., Netemeyer, R.G. and Burton, S. (1990), 'Distinguishing Coupon Proneness from Value Consciousness: An Acquisition-transaction Utility Theory Perspective,' Journal of Marketing, 54 (3), 5467.

20. Lim, H. and Park, J.-S. (2013), 'The Effects of National Culture and Cosmopolitanism on Consumers' Adoption of Innovation: A CrossCultural Comparison,' Journal of International Consumer Marketing, 25 (1), 16-28.

21. Lowe, B. and Barnes, B.R. (2012), 'Consumer Perceptions of Monetary and Non-Monetary Introductory Promotions for New Products,' Journal of Marketing Management, 28 (5-6), 629-651.

22. Lynn, M. (2011), 'Segmenting and Targeting Your Market: Strategies and Limitations,' Cornell University SHA School. [Online], [Retrieved June 29, 2014], http://scholarship.sha.cornell.edu/articles/2 43.

23. Mason, K., Jensen, T., Burton, S. and Roach, D. (2001), 'The Accuracy of Brand and Attribute Judgments: The Role of Information Relevancy, Product Experience, and Attribute-Relationship Schemata,' Journal of the Academy of Marketing Science, 29 (3), 307-317.

24. Miller, N.E. (1959), 'Liberalization of Basic S-R Concepts: Extension to Conflict Behavior, Motivation, and Social Learning,' in
Psychology: A Study of a Science, Koch, S. (ed), McGraw-Hill, New York, New York.

25. Mittal, B. (1994), 'An Integrated Framework for Relating Diverse Consumer Characteristics to Supermarket Coupon Redemption,' Journal of Marketing Research, 31 (4), 533-554.

26. Moreau, C.P., Lehmann, D.R. and Markman, A.B. (2001), 'Entrenched Knowledge Structures and Consumer Response to New Products,' Journal of Marketing Research, 38 (1), 14-29.

27. Mowen, J.C. and Minor, M.S. (2001), Consumer Behavior: A Framework, PrenticeHall, New Jersey.

28. Nobel, C. (2011), ‘Clay Christensen's Milkshake Marketing,' Harvard Business School Working Knowledge, [Online], [Retrieved June 20, 2014], http://hbswk.hbs.edu/pdf/item/6496.pdf.

29. Payne, C.R. and Wansink, B. (2011), 'Quantitative Approaches to Consumer Field Research,' Journal of Marketing Theory and Practice, 19 (4), 377-389.

30. Podsakoff, P.M., MacKenzie, S.M., Lee, J. and Podsakoff, N.P. (2003), 'Common Method Variance in Behavioral Research: A Critical Review of the Literature and Recommended Remedies,' Journal of Applied Psychology, 88 (5), 879-903.

31. Punj, G.N. and Stewart, D.W. (1984), 'An Interaction Framework of Consumer Decision Making,' Journal of Consumer Research, 10 (9), 181-196.

32. Putrevu, S. and Lord, K.R. (1994), 'Comparative and Noncomparative Advertising: Attitudinal Effects under Cognitive and Affective Involvement Conditions,' Journal of Advertising, 23(2), 7790.

33. Putrevu, S. and Ratchford, B.T. (1997), 'A Model of Search Behavior with an Application to Grocery Shopping,' Journal of Retailing, 73 (4), 463-486. 
34. Ramirez, E. and Goldsmith, R.E. (2009), 'Some Antecedents of Price Sensitivity,' Journal of Marketing Theory \& Practice, 17 (3), 199-213.

35. Schiffman, L.G. and Wisenblit, J. (2014), Consumer Behavior, 11 ${ }^{\text {th }}$ Edition, Prentice Hall, Boston, MAassachusetts.

36. Tam, L., Wood, W. and Song, M.J. (2009), 'Brand Loyalty is Not Habitual, ' in Handbook of Brand Relationships, MacInnis, D.J., Park, C.W., and Priester, J.R. (eds), M.E. Sharpe, Armonk, New York.

37. Tellis, G.J., Yin, E. and Bell, S. (2009), 'Global Consumer Innovativeness: CrossCountry Differences and Demographic Commonalities,' Journal of International Marketing, 17 (2), 1-22.

38. Timmor, Y. and Katz-Navon, T. (2008), 'Being the Same and Different: A Model Explaining New Product Adoption,' Journal of Consumer Behaviour, 7 (3), 249-262.

39. Tyagi, C.L. and Kumar, A. (2004), Consumer Behavior, Atlantic, New Delhi, India.
40. Wang, C.-C., Wang, L.-C. and Yang, Y.-J. (2005), 'Innovativeness and Mobile Phone Replacement: An Empirical Study in Taiwan,' Asia Pacific Advances in Consumer Research, 6, 280-283.

41. Wang, G., Dou, W. and Zhou, N. (2008), 'Consumption Attitudes and Adoption of New Consumer Products: A Contingency Approach,' European Journal of Marketing, 42 (1/2), 238-254.

42. Wood, S.L. and Moreau, C.P. (2006), 'From Fear to Loathing? How Emotion Influences the Evaluation and Early Use of Innovations,' Journal of Marketing, 70 (3), 4457.

43. Yoon, K. and Tran, T.V. (2001), 'Revisiting the Relationship between Consumer Loyalty and Price Sensitivity: The Moderating Role of Deal Proneness,' Journal of Marketing Theory and Practice, 19 (3), 293-306. 